\title{
A Preliminary Evaluation of Lablab Biomass Productivity in Virginia ${ }^{\dagger}$
}

\author{
Harbans L. Bhardwaj ${ }^{1} \&$ Anwar A. Hamama ${ }^{1}$ \\ ${ }^{1}$ Agricultural Research Station, Virginia State University, Petersburg, Virginia, USA \\ Correspondence: Harbans L. Bhardwaj, Agricultural Research Station, Virginia State University, Petersburg, \\ Virginia 23806, USA. Tel: 1-804-524-6723. Fax: 1-804-524-5950. E-mail: hbhardwaj@vsu.edu
}

Received: May 9, 2019

doi:10.5539/jas.v11n13p42
Accepted: June 27, 2019 Online Published: August 15, 2019

URL: https://doi.org/10.5539/jas.v11n13p42

${ }^{\dagger}$ Contribution of Virginia State University, Agricultural Research Station. Use of any trade names or vendors does not imply approval to the exclusion of other products or vendors that may also be suitable.

The research was financed by Virginia State University and US Department of Agriculture (NIFA/Evans-Allen Program).

\begin{abstract}
A field study was conducted for two years with seventeen lablab [Lablab purpureus (L.) Sweet] lines to characterize its productivity under Virginia's agro-climatic conditions and to determine lablab's potential as a forage crop. One sample per replication ( $0.3 \mathrm{~m}$ row length) was harvested approximately 90 days after planting to record fresh weight. These samples were dried to a constant weight to record dry weights. Dry and fresh yields were not affected by lines and year of production. Overall means of fresh and dry yields varied from 47 to 91 with a mean of 62, and 9 to 15 with a mean of $13 \mathrm{Mg} / \mathrm{ha}$, respectively. Year of production had significant effects on concentrations of $\mathrm{P}, \mathrm{K}, \mathrm{S}, \mathrm{Mg}, \mathrm{Mn}, \mathrm{Cu}$, and $\mathrm{Zn}$. Concentrations of protein, $\mathrm{P}, \mathrm{K}, \mathrm{Ca}, \mathrm{Mg}, \mathrm{S}, \mathrm{Al}, \mathrm{B}, \mathrm{Cu}, \mathrm{Fe}, \mathrm{Mn}$, $\mathrm{Na}$, and $\mathrm{Zn}$ in lablab produced in Virginia were $15,0.28,2.30,1.32,0.27,0.22,224,20,18,343,79,0.03$, and 40 , respectively. Quality of lablab forage compared well with literature values of other forage legumes especially alfalfa. Lablab biomass in this study contained 60, 45, and 15 percent ADF, NDF, and lignin, respectively indicating that it may also be a potential feedstock for bio-ethanol manufacture.
\end{abstract}

Keywords: Lablab purpureus, Dolichos lablab, ADF, forage legumes, lignin, minerals, NDF, protein concentration

\section{Introduction}

Lablab [Lablab purpureus (L.) Sweet] is a native of Asia and Africa (Pengelly \& Maas, 2001). As per the information available at University of Agricultural Sciences (Bangalore, India), a site well known as a source of information for this crop, lablab is usually known as Dolichos bean, Hyacinth bean or Field bean (www.lablablab.org). It is one of the most ancient crops among cultivated plants, found in archaeo-botanical finds in India prior to $1500 \mathrm{BC}$ (Fuller, 2003) and in Egyptian Nubia from the $4^{\text {th }}$ century AD (Clapham \& Rowley-Conwy, 2007). It is a bushy, semi-erect, perennial herb, showing no tendency to climb. It is one of the major sources of protein in the human diets in southern states of India. The consumer preference varies with pod size, shape, color and aroma (pod fragrance). It is also sometimes grown as an ornamental plant for its beautiful dark-green, purple-veined foliage with large spikes clustered with deep-violet and white pea-like blossoms. Lablab is well known as a forage crop in tropics (Smartt, 1985).

Lablab has been a novelty garden plant in the U.S. for generations. This vigorous twining vine is characterized by larger alternate purple-green leaves and purple petioles. The vines produce hundreds of spikes of lavender flowers in late summer followed by long-lasting deep lavender-purple pods. It is primarily an ornamental annual vine in the US (Anderson et al., 1996). During 1970s, lablab was labelled as "neglected" but worthy of more intensive studies and further developments (NAS, 1979).

Lablab has been noted for decades as being one of the most agro-morphologically diverse (Piper \& Morse, 1915, Pengelly \& Maass, 2001; Islam, 2008) and versatile tropical legume species through its roles as pulse (also used as 'dhal'), vegetable (green bean, pod, leaf), forage/green manure, herbal medicine, and even ornamental (NRC, 2006). Bio-functional properties of lablab for use as pharmaceutical or nutraceutical have also been reviewed 
(Morris, 2009). In Indonesia, seeds serve as raw materials for 'tempeh', a traditional fermented food typically made from soybeans (Subagio \& Morita, 2008).

Use of lablab as a forage crop is well known in tropical and subtropical regions of the world - it can be grazed in a pasture setting or as a companion crop to maize, cut as hay, or mixed with corn silage; and increase livestock weight and milk production during the dry season. Lablab vines make an excellent fodder, Zebu cattle in Brazil were reported to gain $350 \mathrm{~g}$ per head per day over a 3-month period when fed maize stalks and green lablab whereas cattle fed maize without lablab lost weight (www.lablablab.org). A 1963 publication (Schaaffhausen, 1963) indicated that several Dolichos lablab varieties were introduced in 1949 to Brazil from Angola and one variety was distributed to farmers and lists several advantages: a good cover crop; staying green during drought; high yield of green vegetable mass; improves the soil; a palatable fodder (cut, pastured or as silage); of a high protein content; an economic seeding method; and easy harvest of beans.

From a historical perspective, seeds of lablab were planted in 1819 in the Botanical Garden of Sydney, Australia which eventually led to the first improved cultivar, "Rongai" released in Australia in 1962. "Rongai" seed was imported to the US in late 1960s and marketed as supplemental forage for white-tailed deer. Lablab cultivar "Rio Verde" was developed by Texas A\&M AgriLife Research and Extension Center in 2006. This was the first lablab cultivar developed in the US for tolerance to defoliation, forage and seed production (Houck, 2013).

The New Crops Program of Virginia State University (Petersburg, Virginia, USA), established in 1991, has been evaluating a wide array of food, feed, and industrial use crops for diversification of cropping system (Bhardwaj et al., 1996). The objective of the current research with lablab was to characterize its productivity under Virginia's agro-climatic conditions. Specifically, we were interested in developing a baseline of fresh and dry weights and to characterize lablab's chemical composition to assess its forage value.

\section{Materials and Methods}

\subsection{Plant Material}

Sixteen lablab accessions (received from Plant Genetic Conservation Unit, Agricultural Research Service, United States Department of Agriculture, Griffin, GA 30223, USA) and one cultivar "Rio Verde" (Received from Texas A\&M University, Overton, Texas, 75684, USA) constituted the plant materials for this study (Table $1)$.

Table 1. Performance of 17 lablab accessions at Petersburg, Virginia (USA)

\begin{tabular}{|c|c|c|c|c|c|}
\hline \multirow{2}{*}{ Accession } & \multirow{2}{*}{ Source } & \multicolumn{2}{|c|}{ Fresh weight (Mg/ha) } & \multicolumn{2}{|c|}{ Dry weight $(\mathrm{Mg} / \mathrm{ha})$} \\
\hline & & 2011 & 2012 & 2011 & 2012 \\
\hline L60-PI 164772 & India & 49.1 & 44.1 & 9.8 & 8.9 \\
\hline L61-PI 183451 & India & 33.2 & 76.4 & 6.7 & 14.4 \\
\hline L64-PI 284802 & China & 50.8 & 43.1 & 10.3 & 13.4 \\
\hline L65-PI 288466 & India & 62.2 & 62.8 & 13.0 & 15.4 \\
\hline L66-PI 288467 & India & 37.1 & 67.8 & 8.7 & 9.6 \\
\hline L70-PI 388003 & Australia & 69.2 & 57.1 & 13.2 & 12.1 \\
\hline L71-PI 388012 & Australia & 90.8 & 60.0 & 17.8 & 10.6 \\
\hline L72-PI 388013 & Australia & 91.7 & 51.7 & 18.3 & 12.6 \\
\hline L73-PI 388017 & Australia & 71.0 & 51.7 & 16.1 & 12.9 \\
\hline L74-PI 388018 & Australia & 43.6 & 52.8 & 10.0 & 14.1 \\
\hline L80-PI 542609 & India & 63.3 & 47.2 & 15.6 & 10.6 \\
\hline L82-PI 593055 & USA & 76.0 & 93.0 & 12.9 & 16.9 \\
\hline L85-PI 639277 & China & 62.1 & 49.4 & 12.9 & 13.1 \\
\hline L87-PI 639279 & China & 120.7 & 61.5 & 18.0 & 11.0 \\
\hline L88-PI 639280 & China & 72.5 & 59.2 & 13.5 & 6.6 \\
\hline L89-PI 653615 & USA & 73.6 & 82.1 & 10.8 & 17.7 \\
\hline Rio Verde & USA & 66.1 & 40.3 & 14.4 & 9.8 \\
\hline Means & & 66.2 & 58.7 & 12.9 & 12.3 \\
\hline $\mathrm{LSD}_{0.05}$ & & 65.1 & 64.1 & 9.4 & 9.4 \\
\hline
\end{tabular}




\subsection{Production and Sampling}

The seventeen entries of lablab were grown during 2011 and 2012 in the field (Abel sandy loam-Fine Loamy mixed thermic Aquatic Hapridult soil) at Randolph Farm of Virginia State University in Ettrick, Virginia. The planting dates during both years were May 23 and May 15, respectively using two row plots with rows spaced $1.2 \mathrm{~m}$ apart. The field design was a RCBD with two replications. Each plot consisted of two rows with approximately 50 seeds planted in $2.5 \mathrm{~m}$ row length. These plots did not receive any herbicide, insecticide, or fertilizer treatments. The plots were kept weed free manually during the early growth. After about 30 days, the lablab canopy spread enough to crowd-out the weeds. One sample was harvested from each replication for data collection.

\subsection{Data Collection and Statistical Analysis}

At flower initiation (approximately 90 days after planting), all green plants were harvested from $0.3 \mathrm{~m}$ row length of each plot and fresh weights were recorded. A subsample of each plot was dried until constant weight to record dry weights and to determine concentrations of protein, various minerals, ADF, NDF, and lignin. Plant material from all plots were used for nutritional quality analyses. Mineral concentrations, including nitrogen (N), in seed were determined according to AOAC methods (AOAC, 2016) by Waypoint Analytical Laboratory (Richmond, Virginia, USA). Total protein concentration was calculated by multiplying $\mathrm{N}$ content with protein factor 6.25. All data were analyzed using version 9.1 of SAS (SAS Institute, Inc., 2014) using ANOVA with 5\% level of significance. Composition traits of lablab obtained from this study were compared to those in the literature for lablab and other legume forage crops.

\section{Results and Discussion}

\subsection{Fresh and Dry Yields}

The results indicated a lack of significance among seventeen lablab lines, harvested about 90 days after planting, for fresh and dry yields (Table 1). Mean squares for all sources (year, year x entry) were also non-significant. Statistical analyses, individually by years, also indicated lack of significance for all sources for fresh and dry yields. Fresh and dry yields varied from 33 to $121 \mathrm{Mg} / \mathrm{ha}$ with a mean of 66, and 7 to 18 with a mean of 13 $\mathrm{Mg} / \mathrm{ha}$, respectively during 2011 whereas fresh and dry yields varied from 40 to 93 with a mean of 59, and 7-18 with a mean of $12 \mathrm{Mg} / \mathrm{ha}$, respectively during 2012. Overall means of fresh and dry yields (over years) varied from 47 to 91 with a mean of 62 , and 9 to 15 with a mean of $13 \mathrm{Mg} / \mathrm{ha}$, respectively. The dry yields in our study compared quite well with 4 to $12 \mathrm{Mg}$ /ha reported by Murphy and Colucci (1999). Average green matter yields for lablab have been reported to be 5 to $10 \mathrm{Mg} / \mathrm{ha}$ in India (www.lablablab.org). Heuze et al. (2016) indicated that lablab forage yields are around $6 \mathrm{Mg} / \mathrm{ha}$ even though dry yields of $9 \mathrm{Mg} / \mathrm{ha}$ have been reported form Zimbabwe. According to Fribourg et al. (1984), lablab dry matter yields in Tennessee (USA) were 2-5 Mg/ha. We observed that overall moisture content in whole plant lablab harvested about 90 days after planting was 19.5 percent during 2011 and 21.0 during 2012. We speculate that field trials with larger number of entries will exhibit greater and significant variation for fresh and dry yields. We only used two replications for these field trials which resulted in low $\mathrm{R}^{2}$ ( 0.44 percent) and higher coefficients of variation ( 47.2 percent) and believe that field trials with more replications might exhibit significant differences among lablab entries for fresh and dry yields.

\subsection{Chemical Composition}

Chemical composition of whole plant lablab, approximately 90 days old, when grown in Virginia during 2011 and 2012 are presented in Table 2. Effects of entries on chemical composition of lablab in this study were non-significant, however, year of production had significant effects on concentrations of $\mathrm{P}, \mathrm{K}, \mathrm{S}, \mathrm{Mg}, \mathrm{Mn}, \mathrm{Cu}$, and $\mathrm{Zn}$. Concentrations of protein, $\mathrm{P}, \mathrm{K}, \mathrm{Ca}, \mathrm{Mg}, \mathrm{S}, \mathrm{Al}, \mathrm{B}, \mathrm{Cu}, \mathrm{Fe}, \mathrm{Mn}, \mathrm{Na}$, and $\mathrm{Zn}$ in lablab produced in Virginia were $15,0.28,2.30,1.32,0.27,0.22,224,20,18,343,79,0.03$, and 40 , respectively. Protein concentration in whole plant lablab in our study was slightly lower than that reported in the literature which varied from 13 to 18 percent (Table 2). The range in protein concentrations in our study (12.7 to 16.1) was also lower than that from values in literature (12.5 to 24.3, Heuze et al., 2016). ADF, NDF, and lignin concentrations $(60,45$, and 15, respectively) in our study were greater than those reported by Heuze et al., in 2016 (45, 32, and 7, respectively). 
Table 2. Mean chemical composition of lablab biomass at Petersburg, Virginia (USA) and literature values

\begin{tabular}{lllll}
\hline Trait & Lablab $^{1}$ & Lablab $^{2}$ & Lablab $^{3}$ & Lablab $^{4}$ \\
\hline Protein (\%) & $15.0(12.7-16.1)$ & $13.2-22.2$ & $18.4(12.5-24.3)$ & 18 \\
P (\%) & $0.28(0.32-0.24)$ & $1.7-4.4$ & $0.29(0.19-0.55)$ & $\mathrm{n} / \mathrm{a}$ \\
K (\%) & $2.30(2.03-2.47)$ & $1.76-3.61$ & $0.23(0.10-0.35)$ & $\mathrm{n} / \mathrm{a}$ \\
$\mathrm{Ca}(\%)$ & $1.32(1.18-1.61)$ & $0.87-1.80$ & $1.30(0.74-2.18)$ & $\mathrm{n} / \mathrm{a}$ \\
$\mathrm{Mg}(\%)$ & $0.27(0.24-0.31)$ & $0.27-0.46$ & $0.35(0.27-0.65)$ & $\mathrm{n} / \mathrm{a}$ \\
$\mathrm{S}(\%)$ & $0,22(0.19-0.24)$ & $\mathrm{n} / \mathrm{a}$ & $\mathrm{n} / \mathrm{a}$ & $\mathrm{n} / \mathrm{a}$ \\
$\mathrm{Al}(\mathrm{ppm})$ & $\mathrm{n} / \mathrm{a}$ & $\mathrm{n} / \mathrm{a}$ & $\mathrm{n} / \mathrm{a}$ \\
$\mathrm{B}(\mathrm{ppm})$ & $224(110-554)$ & $\mathrm{n} / \mathrm{a}$ & $\mathrm{n} / \mathrm{a}$ & $\mathrm{n} / \mathrm{a}$ \\
$\mathrm{Cu}(\mathrm{ppm})$ & $20(17-24)$ & $\mathrm{n} / \mathrm{a}$ & $504(175-833)$ & $\mathrm{n} / \mathrm{a}$ \\
Fe (ppm) & $18(13-25)$ & $\mathrm{n} / \mathrm{a}$ & $\mathrm{n} / \mathrm{a}$ & $\mathrm{n} / \mathrm{a}$ \\
Mn (ppm) & $343(134-1089)$ & $\mathrm{n} / \mathrm{a}$ & $0.17(0.10-0.21)$ & $\mathrm{n} / \mathrm{a}$ \\
Na (ppm) & $79(42-146)$ & $0.10-0.54$ & $\mathrm{n} / \mathrm{a}$ & $\mathrm{n} / \mathrm{a}$ \\
Zn (ppm) & $0.03(0.03-0.03)$ & $\mathrm{n} / \mathrm{a}$ & $44.6(36.0-53.8)$ & 35 \\
ADF (\%) & $40(34-48)$ & $\mathrm{n} / \mathrm{a}$ & $32.0(22.8-41.4)$ & $\mathrm{n} / \mathrm{a}$ \\
NDF (\%) & $60.1(57.4-67.1)$ & $\mathrm{n} / \mathrm{a}$ & $7.2(4.6-10.7)$ & $\mathrm{n} / \mathrm{a}$ \\
Lignin (\%) & $45.5(42.6-50.5)$ & $\mathrm{n} / \mathrm{a}$ & & \\
\hline
\end{tabular}

Note. ${ }^{1}$ : Current study. Means based on 17 accessions, two reps, and two years. Minimum and maximum values are presented in parenthesis). ${ }^{2}$ : Shehu et al. (2001). ${ }^{3}$ : Heuze et al. (2016). ${ }^{4}$ : Mullen, C. (2019).

Comparison of protein concentration in 90 day old whole lablab plants grown in Virginia (Table 3) indicated that even though lablab had slightly lower concentration as compared to alfalfa, Tepary bean, and white lupin, lablab forage is potentially acceptable given that its nutritional quality was, generally, comparable to that of alfalfa.

Table 3. Forage quality of lablab produced in Virginia in comparison to other forage crops

\begin{tabular}{|c|c|c|c|c|}
\hline Trait & Lablab $^{1}$ & White lupin $^{2}$ & Tepary bean ${ }^{3}$ & Alfalfa ${ }^{4}$ \\
\hline Protein (\%) & $15.0(12.7-16.1)$ & 18.7 & 21.4 & 19.0 \\
\hline $\mathrm{P}(\%)$ & $0.28(0.32-0.24)$ & - & 0.28 & 0.2 \\
\hline $\mathrm{K}(\%)$ & $2.30(2.03-2.47)$ & - & 2.49 & 1.8 \\
\hline $\mathrm{Ca}(\%)$ & $1.32(1.18-1.61)$ & - & 2.11 & 1.3 \\
\hline $\operatorname{Mg}(\%)$ & $0.27(0.24-0.31)$ & - & 0.54 & 0.4 \\
\hline S (\%) & $0,22(0.19-0.24)$ & - & 0.27 & - \\
\hline $\mathrm{Al}(\mathrm{ppm})$ & $224(110-554)$ & - & 229 & - \\
\hline $\mathrm{B}(\mathrm{ppm})$ & $20(17-24)$ & - & 20.9 & - \\
\hline $\mathrm{Cu}(\mathrm{ppm})$ & $18(13-25)$ & - & 9.27 & 12.0 \\
\hline $\mathrm{Fe}(\mathrm{ppm})$ & $343(134-1089)$ & - & 308 & - \\
\hline $\mathrm{Mn}(\mathrm{ppm})$ & $79(42-146)$ & - & 359 & - \\
\hline $\mathrm{Na}(\mathrm{ppm})$ & $0.03(0.03-0.03)$ & - & 0.05 & - \\
\hline $\mathrm{Zn}(\mathrm{ppm})$ & $40(34-48)$ & - & 39.5 & 30.0 \\
\hline $\operatorname{ADF}(\%)$ & $60.1(57.4-67.1)$ & 23.7 & 37.5 & 32.0 \\
\hline NDF $(\%)$ & $45.5(42.6-50.5)$ & - & 41.1 & 40.0 \\
\hline Lignin (\%) & $15.1(10.9-26.4)$ & - & - & - \\
\hline
\end{tabular}

Note. ${ }^{1}$ : Current study. Means based on 17 accessions, two reps, and two years. Minimum and maximum values are presented in parenthesis). ${ }^{2}$ : Bhardwaj, Starner, and van Santen (2010). ${ }^{3}$ : Bhardwaj, 2013. ${ }^{4}$ : Meyer et al. (2010).

We conclude that, generally, lablab produced in Virginia as a summer crop, had acceptable chemical composition to indicate that lablab could be a potential nutritional summer forage crop in Virginia. 


\subsection{Lablab Biomass as a Feedstock for Ethanol Production}

Based on results of El-Nashaar et al. (2009) indicating that concentrations of Al, P, K, and S (ppm) in switchgrass (44 to 111,1297 to 5656,6481 to 15806,467 to 1133 , respectively) are suitable, generally, for its thermochemical conversion to ethanol and given that corresponding concentrations in lablab biomass (110 to 554,2400 to 3200,20300 to 24700,1900 to 2400 , respectively) are quite comparable, we suggest that lablab biomass may also be a potential feed stock for bio-ethanol. One advantage of using lablab biomass as a feedstock for bio-ethanol will be the Symbiotic N Fixation by lablab which could reduce/eliminate use of N fertilizers. This aspect needs to be explored further.

\section{Conclusions}

This study indicated that lablab [Lablab purpureus (L.) Sweet] is a potential forage crop in mid-Atlantic region of the United States of America since agro-climatic conditions in Virginia are representative of those in mid-Atlantic region. Additionally, lablab biomass may also have potential as a feedstock for synthesis of bio-ethanol.

\section{Acknowledgements}

Authors are thankful to Virginia State University and US Department of Agriculture (NIFA/Evans-Allen Program) for supporting this research with financial and physical resources. Authors also thank Dr. John Fike (Virginia Tech) for ADF, NDF, and Lignin determinations.

\section{References}

Anderson, G. R., Bale, S., \& Jia, W. (1996). Hyacinth bean: Stems for the cut flower market (pp. 540-542). Progress in New Crops, ASHS Press, Arlington, VA.

AOAC (Association of Official Analytical Chemists). (2016). Official Methods of Analysis (20th ed.). AOAC, Arlington, VA. Retrieved from http://www.aoac.org/aoac_prod_imis/AOAC/AOAC_Member/PUBSCF/ OMACF/OMAP_M.aspx

Bhardwaj, H. L. (2013). Preliminary evaluation of Tepary bean (Phaseolus acutifolius A. Gray) as a forage crop. Journal of Agricultural Science, 5(9), 160-166. https://doi.org/10.5539/jas.v5n7p160

Bhardwaj, H. L., A. Hankins, T., Mebrahtu, J., Mullins, M., Rangappa, O. A., \& Wellbaum, G. E. (1996). Alternative Crops Research in Virginia. In J. Janick (Ed.), Progress in new crops (pp. 87-96). ASHS Press, Alexandria, VA.

Bhardwaj, H. L., Starner, D. E., \&van Santen, E. (2010). Preliminary evaluation of white lupin (Lupinus albus L.) as a forage crop in the Mid-Atlantic region of the United States of America. Journal of Agricultural Science, 2(4), 13-17. https://doi.org/10.5539/jas.v2n4p13

Blade, S. F., \& Slinkard, A. E. (2002). New crop development: The Canadian experience. In J. Janick, \& A. Whipkey (Eds.), Trends in New Crops and New Uses (pp. 62-75). ASHS Press, Alexandria, VA.

Clapham, A., \& Rowley-Conwy, P. (2007). New discoveries at Qasr Ibrim, Lower Nubia. In R. Cappers (Ed.), Fields of change: Progress in African archaeobotany (pp. 157-164). Barkhuis \& Groningen University Library, Groningen, the Netherlands.

El-Nashaar, H. M., Banowetz, G. M., Griffith, S. M., Casler, M. D., \& Vogel, K. P. (2009). Genotypic variability in mineral composition of switchgrass. Bioresource Technology, 100, 1809-1814. https://doi.org/10.1016/ j.biortech.2008.09.058

Fletcher, R. J. (2002). International new crop development incentives, barriers, processes, and progress: An Australian experience. In J. Janick, \& A. Whipkey (Eds.), Trends in New Crops and New Uses (pp. 40-54). ASHS Press, Alexandria, VA.

Fribourg, H. A., Overton, J. R., McNeill, W. W., Culvahouse, E. W., Montgomery, M. J., M. Smith, R. J. ... Robinson, N. W. (1984). Evaluations of the potential of hyacinth bean as an annual warm-season forage in the Mid-South. Agronomy Journal, 76, 905-910. https://doi.org/10.2134/agronj1984.000219620076000 $60011 \mathrm{x}$

Fuller, D. Q. (2003). African crops in prehistoric South Asia: A critical review. In K. Neumann, A. Butler, \& S. Kahlheber (Eds.), Food, fuel, fields-Progress in African archaeobotany (Vol. 15, pp. 2139-271). Africa Praehistorica. 
Heuze, V., Tran, G., Stewart, D., Renaiudeau, D., \& Lebas, F. (2016). Lablab (Lablab purpureus). Feedipedia, a Programme by INRA, CIRAD, AFZ and FAO. Retrieved from https://www.feedipedia.org/node/297

Houck, M. J. (2013). Lablab (Lablab purpureus) for Conservation Use in Louisiana. Plant Material Technical Note No. 21. US Department of Agriculture, Natural Resources Conservation Service, Alexandria, LA.

Islam, M. T. (2008). Morpho-agronomic diversity of hyacinth bean (Lablab purpureus (L.) Sweet) accessions from Bangladesh. Plant Genet Resource Newsletter, 156, 72-77.

Johansen, H. N., Gilts, V., \& Knudsen, K. E. N. (1996). Influence of Extraction Solvent and Temperature on the Quantitative Determination of Oligosaccharides from Plant Materials by High-Performance Liquid Chromatography. J. Agric. Food Chem., 44, 1470-1474. https://doi.org/10.1021/jf950482b

Magness, J. R., Markle, G. M., \& Compton, C. C. (1971). Food and Feed Crops of the United States. Interregional Research Project IR-4, IR Bul.1 (Bul.828 New Jersey Agri. Expt. Sta.).

Meyer, R., L. Warren, J. Eckert, D. Hancock, A. B., \& Olson, C. (2010). Perennial peanut: Forage nutritional composition and feeding value. Animal Science Department, Florida Cooperative Extension Service, Institute of Food and Agricultural Sciences, University of Florida. Retrieved from http://edis.ifas.ufl.edu

Morris, J. B. (2009). Morphological and reproductive characterization in hyacinth bean, Lablab purpureus (L.) Sweet germplasm with clinically proven nutraceutical and pharmaceutical traits for use as a medicinal food. J Diet Suppl, 6(3), 263-279. https://doi.org/10.1080/19390210903070830

Mullen, C. (2019). Summer legume forage crops: Cowpeas, lablab, soybeans. Retrieved from https://www.dpi. nsw.gov.au/agriculture/broadacre-crops/forage-fodder/crops/summer-legume-forage

Murphy, A. M., \& Colucci, P. E. (1999). A tropical forage solution to poor quality ruminant diets: A review of Lablab purpureus. Livestock Research for Rural Development, 11(2), 1-16.

NAS (National Academy of Sciences). (1979). Lablab Bean, Tropical Bean, Tropical Legumes: Resources for the Future. National Academy of Sciences, Washington, D.C., USA.

NRC (National Research Council). (2006). Lablab-Lost crops of Africa (Vol. II, pp. 190-205). NRC, Washington, DC, USA.

Pengelly B. C., \& Maass, B. L. (2001). Lablab purpureus (L.) Sweet—Diversity, potential use and determination of a core collection of this multipurpose tropical legume. Genet Resour Crop Evol, 48, 261-272.

Piper, C. V., \& Morse, W. J. (1915). The bonavist, lablab or hyacinth bean. USDA Bull (Vol. 318, pp. 1-15). USDA, Washington DC, USA. https://doi.org/10.5962/bhl.title.109172

SAS. (2014). SAS for Windows Version 9.4. SAS Institute, Cary, N.C. Retrieved from http://www.sas.com/ en_us/software/sas9.html

Schaaffhausen. (1963). Dolichos lablab or Hyacinth Bean: Its Uses for Feed, Food and Soil Improvement. Economic Botany, 17, 146-153. https://doi.org/10.1007/BF02985365

Shehu, Y., Alhassan, W. S., Pal, U. R., \& Phillips, C. J. C. (2001). The effects of Plant Population Density on the Growth and Chemical Composition of Lablab purpureus Grown for Fodder Production in a Semi-Arid Region. J. Agronomy \& Crop Science, 186, 83-89. https://doi.org/10.1046/j.1439-037X.2001.00455.x

Smartt, J. (1985). Evolution of grain legumes. II. Old and new world pulses of lesser economic importance. Exp. Agri., 21, 1-18. https://doi.org/10.1017/S0014479700012205

Subagio, A., \& Morita, N. (2008). Effects of protein isolate from hyacinth beans (Lablab purpureus (L.) Sweet) seeds on cake characteristics. Food Sci Technol Res, 14(1), 12-17. https://doi.org/10.3136/fstr.14.12

\section{Copyrights}

Copyright for this article is retained by the author(s), with first publication rights granted to the journal.

This is an open-access article distributed under the terms and conditions of the Creative Commons Attribution license (http://creativecommons.org/licenses/by/4.0/). 